\title{
Kunst in Kampf für das "Sozialistische Weltsystem": Auswärtige Kulturpolitik der DDR in Afrika un Nahost. By Christian Saehrendt. Stuttgart: Franz Steiner Verlag, 2017. 164 pp. Notes. Bibliography. Chronology. Illustrations. Photographs. $€ 39.00$, hard bound.
}

doi: 10.1017/slr.2018.315

At various levels, the German Democratic Republic (GDR) acted as a junior partner of the Soviet Union in the Third World during the Cold War, endeavoring to promote state building not only through assistance and cooperation in the fields of technology, economics, and administration, but also through the export of science, culture, and ideology. Exchanges of art exhibitions and scholarship programs as well as assistance in setting up new art academies served as policy instruments aimed at consolidating and progressively integrating a "socialist world system." Set in this framework, Christian Saehrendt's Kunst im Kampf focuses on the cultural-political relations between the GDR and select states in west Africa (Mali, Guinea), east Africa (Tanzania, Ethiopia) and south Africa (Angola, Mozambique), as well as with Syria, Iraq, and the Palestinian Liberation Movement in the Middle East (8). The research is based on a broad synthesis of existing secondary literature and original research in German archives.

The book is organized in five chapters. The first one offers a somewhat detailed definition and discussion of a number of concepts as "soft power," "national branding," and "nation building," among others. It also provides a series of examples of today's uses of contemporary "national branding" techniques through art by countries which the author refers to as "new despots" (Neuen Despotien), such as Russia, China, Qatar, and Iran. The second chapter sets the stage for the GDR, describing the institutional framework behind East Berlin's "foreign cultural policy" (Auswärtige Kulturpolitik). The next two chapters look at the GDR's cultural relations with states newly formed in the 1960s in Africa and the Middle East, offering a brisk historic overview of the general political trends in those countries and a compendium of brief catalogue mentions of cultural exchanges occurring on bilateral basis. By means of conclusion in the final chapter, Saehrendt offers some general "open questions" which bridge his discussion on the GDR's cultural policy with similar strategies adopted by the so-called "new despots."

Regarding the GDR, the author focuses on the use of cultural diplomacy as an instrument of "national branding." As he demonstrates, the foreign cultural policy was aimed at benefiting the GDR's recognition policy, in which artists became diplomats, repeatedly striving to break international isolation, to borrow Ulrich Pfeil's observation (38). In this way, East Berlin sought to undermine the Hallstein doctrine and attempt to exert a sustainable influence on the new nation states. This led to fervent cultural exchange, as in the fall of 1974 alone, for example, when 8,000 artists from the GDR were involved in "propagating socialism" in as many as seventy-two states (40). This was, however, as Saehrendt claims "false" cultural exchange ("falsche" Kulturaustausch) (152), as it only appeared to be reciprocal, being in reality a markedly one-sided phenomenon. Resulting from a highly hierarchical and bureaucratic allocation, it lacked any alternative channels of communication and coordination, justified by the notion that a denser network of international cultural relations would endanger the legitimacy of the German Socialist Unity Party's (SED) domination at home by potentially increasing its exposure to western influence (149). As the author points out, this highly structured, government-controlled, cultural exchange remains relevant today in Russia, China, Iran, and Turkey, which export their own art and values through official channels, but hinder private and non-governmental exchanges in order 
to prevent "contaminating" their societies with western values. The center of Saehrendt's thesis, therefore, zeroes in on the ambivalence of art as a "virus of freedom" (Virus der Freiheit) (154), which had to be tamed and contained by centralized political institutions during the Cold War for its potential political subversive qualities, a feature he recognizes even today.

This short, competently written book offers an engaging, insightful discussion. While it might not impress the reader by its original fact-finding, it raises a plethora of relevant questions, the answers to which can barely be made in a conceivable manner in a 164-page opus. The parallels drawn between the GDR of the twentieth century and Russia, China, Iran, and Qatar of the twenty-first century, while requiring a series of caveats for a thorough like-for-like comparison, are nonetheless important in signaling the modes in which art and culture intersects with high politics across two markedly different international world systems. This monograph should therefore appeal to art history students as well as to international historians, not only for providing skillfully-drawn snapshots of two decades of East Berlin's cultural diplomacy towards a number of states in Africa and the Middle East, but also for its compelling cross-cultural and historic references. While not a definitive study, the reviewed monograph is a serious attempt at delving into a complex and often neglected "soft power" tool in the historiography, one which bears on more tangible sources of political influence, a notion that itself makes such studies a noteworthy contribution to better understanding the intricate world of international politics.

RADOSLAV YORDANOV Harvard University, Davis Center for Russian and Eurasian Studies

The Economic Struggle for Power in Tito's Yugoslavia: From World War II to Non-Alignment. By Vladimir Unkovski-Korica. London: I.B. Tauris, 2016. x, 294 pp. Notes. Index. Photographs. \$110.00, hard cover.

doi: 10.1017/slr.2018.316

One way of looking at Yugoslavia's development of its separate road to socialism is through its efforts to develop an export economy. This has not been the methodology most commonly employed by Balkan and Cold War historians up to this point, and that is putting things mildly. Building a history of socialist Yugoslavia on the conceptual lens or jumping-off point of export economics would seem to be a tall order, recasting or overturning decades of historiography centered on political stimuli, the interaction of strong personalities, and ideological innovations in favor of analysis building on recognition of the fundamental economic ties to the west rather than the east of Yugoslavia under Josip Broz Tito. But this is the challenge that Vladimir Unkovski-Korica sets for himself in this substantial new volume. In the key chapter of the work, "Unravelling Self-management," he writes that "the Yugoslav Communist hope to open up to and integrate more fully in the world market in the 1960s led to major domestic problems" (217). For this proposition to make sense, and for this assertion to be demonstrated, the author must consider the interplay of economic and political forces in Yugoslavia twenty years earlier, in the mid-1940s, even before the break with Stalin. At the level of policy-making, by using archival accounts of meetings and speeches and reports, the author achieves this goal. He also takes the time to track, wisely and lucidly, the role of individual movers and shakers on economic issues in the League of Communists, from Boris Kidrič and Svetozar Vukmanović-Tempo to Edvard Kardelj 